\title{
Genetics in the United Kingdom - The Last Half-Century
}

\author{
J. R. S. FINCHAM
}

This year's 16th International Congress of Genetics in Birmingham is the first to be held in the United Kingdom since the 7th (Edinburgh) Congress in 1939, just before the outbreak of war. This historical essay is an attempt to chart the most important developments in U.K. genetics between these two Congresses or, more precisely, during the post-war period. I have tried to identify the institutions and schools that have had the greatest influence on the growth of our subject, and to trace the connections between them. I must to some extent be biased by my own partial view of the field, and $I$ apologize for any serious omissions.

\section{The early post-war scene}

In 1945 there were only a few centres in the U.K. for teaching and research in genetics. There was the John Innes Horticultural Institution (now the John Innes Institute), then located in Merton, South London, with C.D. Darlington as Director. There were three institutions concerned with plant breeding: the Plant Breeding Institute in Cambridge and the Welsh and Scottish Plant Breeding Stations, near Aberystwyth and Edinburgh, respectively. In University College, London, there was the Galton Laboratory, with L. S. Penrose as the Galton Professor of Eugenics, and the Department of Biometry and Genetics with J. B. S. Haldane as Professor of Biometry. In Cambridge, R. A. Fisher presided over a small Department of Genetics accommodated in an extension to his private house, while, on the other side of town in the Botany School, several young geneticists and cytologists were working under the guidance of D. G. Catcheside. In the Oxford Zoology Department, E. B. Ford, with his population studies on Lepidoptera, was a pioneer in ecological genetics.

The immediate post-war period was a time of new departures. In 1945, C. H. Waddington was appointed head of the Genetics Section of the newly established Animal Breeding and Genetics Research Organization (ABGRO - later ABRO), funded by the Agricultural Research Council (ARC). IN 1946, the Organization moved from London to Edinburgh, where Waddington had been appointed to the Chair of Genetics in succession to F. A. E. Crew. This appointment led to many further developments, of which more below.

On the other side of Scotland, Guido Pontecorvo was starting a new Department of Genetics at Glasgow
University, and establishing the fungus Aspergillus nidulans as a model microbial eukaryote for genetic studies. The Cambridge University Botany School was another growth point for fungal genetics; Harold Whitehouse had already completed his Ph.D. work on Neurospora sitophila and David Catcheside was about to import Neurospora crassa from CalTech. In R. A. Fisher's Genetics Department, L. L. Cavalli-Sforza was starting the work on the genetics of $E$. coli that was to lead to his discovery of one of the first two highfrequency-recombination strains, HfrC. The other, $\mathrm{HfrH}$, was found a little later by W. (Bill) Hayes, of the London Postgraduate Medical School in Hammersmith. Hayes became the leader of the subsequent great expansion of bacterial genetics in the U.K.

Two members of the John Innes Institution left to seed genetics elsewhere. P. T. Thomas became Professor of Agricultural Botany in the University of Wales, Aberystwyth to teach a generation of Welsh plant cytologists and geneticists, several of whom $(\mathrm{H}$. J. Evans, H. Rees, E. A. Bevan, K. W. Jones) are mentioned below. And in 1948 Kenneth Mather moved to Birmingham University to found a new Department of Genetics and a powerful school of biometrical genetics, the most notable member of which, from the mid-1950s, was John L. Jinks, who succeeded Mather to the Chair in 1965. In 1950 Darlington and the John Innes moved from Merton to a fine country estate in Bayfordbury, Hertfordshire.

\section{Early MRC initiatives}

Some of the most significant early post-war developments took place under the auspices of the Medical 
Research Council (MRC). Most important of all, in that it was about to revolutionize our subject, was the MRC Molecular Biology Unit, established in Cambridge in 1947 with Max Perutz as Director and John Kendrew as his deputy. This Unit was concerned mainly with protein crystallography, but it also provided the venue for Jim Watson and Francis Crick's momentous elucidation of DNA structure. A few years later it played host for a while to Seymour Benzer, who was then engaged on his demolition of the classical concept of the gene. The Cambridge MRC Unit was the direct precursor of the MRC Laboratory of Molecular Biology, established in 1962 in a large new building on Hills Road with an all-star staff including Francis Crick, Fred Sanger and Sydney Brenner. Crick and Brenner led the molecular genetics group and attacked the coding problem, with results too well-known to need description here.

Another MRC initiative was their establishment of the Radiobiology Research Unit in Harwell. The interests of this Unit were by no means confined to radiation. In the $1950 \mathrm{~s}, \mathrm{C}$. E. Ford carried out the first definitive studies on human chromosomes in meiosis. In 1961 Mary Lyon demonstrated X-chromosome inactivation in female mice; she had started her work in Edinburgh where the Harwell Unit had an outpost in its early days. It was in Edinburgh that Charlotte Auerbach had (during the war) discovered chemical mutagenesis. In 1958 the MRC established a Mutagenesis Unit there under her direction, which was continued until her retirement.

The 1950s saw the first flowering of bacterial and bacteriophage genetics in the U.K., and this too was largely funded by the MRC In 1957 an MRC Unit of Molecular Genetics was set up under Bill Hayes at Hammersmith Hospital. This soon became an extremely strong international centre for the development of $E$. coli genetics in all its aspects. At the same time, Martin Pollock, at the MRC National Institute for Medical Research (NIMR) at Mill Hill (North London), was working on bacterial enzyme induction, interacting with Jacques Monod's group in Paris. Pollock and Hayes and their respective colleagues (including almost the whole strong Hammersmith group) were later (1968) to join forces in a new, impressively housed Molecular Biology Department in the University of Edinburgh - a successful hybrid between an MRC Institute and a University teaching department.

In 1956, after the clarification by Tjio and Levan in Sweden of the human karyotype, the time was ripe for a new initiative in human cytogenetics, and the MRC set up the Clinical and Population Cytogenetics Unit (now the Human Genetics Unit) at the Edinburgh
Western General Hospital under the direction of W. H. Court Brown. Since 1969 it has been headed by H. John Evans. Though modestly called a Unit, it became a substantial Institute of international importance, with special strength in innovative chromosome technology, characterization of human chromosome aberrations, and research on radiation effects, with extensive use of the mouse as a model mammal.

\section{The expansion of genetics in the Universities}

\section{The earliest Genetics Departments}

At the end of the 1940s there were independent Departments of Genetics in four Universities - the long-established departments in Cambridge and Edinburgh and the new ones in Birmingham and Glasgow.

Edinburgh was the first of these to undergo major development. Soon after its move to Edinburgh in 1947, ABGRO was divided into the Animal Breeding Research Organization (ABRO), a free-standing Institute under H. P. Donald, later accommodated on the University campus, and the Agricultural Research Council ARC Unit of Animal Genetics, which was assimilated into the University Department to form the Institute of Animal Genetics with Waddington as Head. This ARC Unit became famous for its work on the theory and practice of selection, with Alan Robertson (Drosophila and cattle) and Douglas Falconer (mice) as the leading figures. This interest, combined with theoretical population genetics, continues to flourish in Edinburgh under the leadership of Robertson's student and successor W. G. (Bill) Hill. It had, and still has, a strong teaching aspect in the form of a unique postgraduate course in animal breeding, run in collaboration with the ABRO staff.

With their emphasis on animals, random mating and small populations, the Edinburgh quantitative geneticists differed from their Birmingham counterparts (who were also supported by the ARC) both in methodology and, to some extent, in philosophy. This difference at least partly accounts for our having two general genetics journals, Heredity and Genetical Research (the longer-established Journal of Genetics was taken by Haldane to India in 1957). Genetical Research, which started in 1960, was edited from the Institute of Animal Genetics by Eric Reeve, who has continued in the job to this day.

Waddington's own interest included both selection and animal development. His experiments on selection for response to temperature stress led to his concept of genetic assimilation, and his thinking about development to his ideas about canalization - modelled as 'epigenetic landscapes'. For support for these interests 
he turned to the MRC, and, from 1963, obtained funding for an Epigenetics Unit, which obtained its own building. The Edinburgh Epigenetics group, particularly Max Birnstiel, Ken Jones and John Bishop, made a big mark in animal molecular biology, with pioneering work on such topics as rRNA genes, in situ hybridization of probes to chromosomes, and analysis of RNA transcripts. Most of the work on actual animal development was done in the ARC Unit, especially by Anne McLaren. There was never, in fact, any clear division of territory between the differently funded groups. Anne McLaren left in 1974 for University College, London, where Hans Grüneberg had been working since the war on mouse developmental genetics.

Another unique feature of the Edinburgh Institute of Animal Genetics was Geoffrey Beale's work on the unusual genetic systems of Paramecium aurelia. In the 1970 s his protozoan group extended its interests to include pathogens such as trypanosomes (Andrew Tait, who has now moved to Glasgow) and malaria parasites (David Walliker, who remains in Edinburgh).

The Cambridge Genetics Department, distinguished but very small under Fisher, underwent a metamorphosis following the appointment of John M. Thoday to the Chair in 1959. Thoday, who obtained his Ph.D. under Catcheside in the Cambridge Botany School, had moved to Sheffield University in 1948 and become Head of a new Department of Genetics there in 1954. In Cambridge he obtained more adequate accommodation for the Genetics Department, first in the northern outskirts of town but eventually (1976) in the former Department of Agriculture building in the central science area. During the 1960s the department developed all-round strength. Perhaps because of my fungal bias, I give special importance to the Aspergillus nidulans group (John Pateman, David Cove, Claudio Scazzocchio, Herbert Arst) who extended the range of the organism from formal genetics to biochemical (and later molecular) genetics, setting in train a great expansion of Aspergillus work internationally. This was the second subculture in the U.K. of Aspergillus nidulans from its Glasgow source, the first being in Sheffield, where J. Alan Roper, from Pontecorvo's department, succeeded Thoday as Professor and Head of Department. In more recent years the Cambridge Department has become the main U.K. centre for Drosophila genetics, mainly through the efforts of Michael Ashburner.

In Birmingham, Mather's Department was always a stronghold of biometrical genetics, a position it maintained under John Jinks. Like Edinburgh, but from a somewhat different angle, it set up a taught post-graduate course in this field. But it also developed other areas, notably cytology (Hubert Rees and later Gareth Jones) and bacterial genetics (Derek Smith, the Secretary of the present International Congress).

The Glasgow Department's great strength, derived from Pontecorvo, was always in Aspergillus genetics, which was important not only in itself but also for its impact on genetics in general. It resulted in the first evidence (mainly arising from the work of Alan Roper and R. H. (Bob) Pritchard) for the subdivisibility by recombination of the functional gene. It also showed the potential, later much used in mammalian cell genetics, of parasexual systems of analysis, based on nuclear fusion and subsequent chromosome loss in vegetative cells. As we shall see, several of Pontecorvo's younger colleagues of the $1950 \mathrm{~s}$ went on to become leaders of genetics in other Universities. The Aspergillus tradition was maintained after John Pateman succeeded to the Chair in 1970; the medical genetical connection was strengthened through Malcolm Ferguson-Smith. From the 1960s, Glasgow University also became a major centre for virus genetics; the leading geneticist in the MRC Virus Research Unit was John Subak-Sharpe, formerly a member of the Department of Genetics, who became Director of the Unit in 1969.

\section{The botanical connection}

Apart from the first four separate Genetics Departments, the initial post-war expansion of University genetics was mainly in Departments of Botany. By 1950, two of David Catcheside's recent Ph.D. students, George Dawson and myself, had left the Cambridge Botany School for other Botany departments George for Trinity College, Dublin and I for Leicester. In Cambridge, although Catcheside himself left in 1952 for Adelaide, the genetical strength of the Botany School was maintained by Harold Whitehouse. In addition to his own influential work on recombination, Whitehouse launched numerous Ph.D. graduates, including Robin Holliday and David Hopwood - and their respective organisms, Ustilago and Streptomyces.

The role of $\mathrm{P}$. T. Thomas in the Aberystwyth Department of Agricultural Botany has already been mentioned. After his appointment, in 1966, as Director of the Welsh Plant Breeding Station he was succeeded in the University Chair by his former student Hubert Rees, who had spent some of the intervening years in Mather's department in Birmingham. Under Rees' guidance, Aberystwyth continues as a leading centre of plant cytology.

In 1957 Dan Lewis moved from the Headship of the Genetics Department of the John Innes to take the Chair of Botany at University College, London, where 
he continued to pursue his interest in systems of selfincompatibility, now extended from cherries to the fungus Coprinus lagopus. His main genetical colleague there was David Wilkie (from Pontecorvo's group), who became one of the pioneers of mitochondrial genetics of yeast. The Coprinus work was later taken over, to great effect, by Lewis's student Lorna Casselton, who is now a Professor in the Oxford Botany Department.

Again in 1957, C. D. Darlington gave up the Directorship of the John Innes on his election to the Chair of Botany in Oxford. This gave a botanical dimension to Oxford genetics, to complement E. B. Ford in the Zoology Department. One of Darlington's first appointments was E. Alan Bevan, again from Pontecorvo's Glasgow group. Bevan later moved on to the Chair of Botany at Queen Mary College, London. His investigation of the 'killer' phenomenon in yeast led to his discovery of double-stranded RNA plasmids.

David Catcheside returned to the U.K. in 1957 (I believe at Mather's instigation) to become Professor and Head of Department of Microbiology in the University of Birmingham. This became in effect a department of microbial genetics. Catcheside and his Birmingham students (including, most notably, Noreen Murray, now a Professor in Edinburgh) did definitive work on complementation maps and controls of recombination in Neurospora crassa. In 1964 he returned to Australia to take charge of genetics in the Research School of Biological Sciences in Canberra.

\section{The spread of Genetics Departments}

From the mid-1950s, and especially in the 1960s and early 1970 s, the belief grew that any self-respecting University should have a Department of Genetics. First in the field was Sheffield, as already noted. In the same year, 1954, my genetics laboratory in Leicester was given departmental status, but it was never much more than a one-man show. When I moved in 1960 to succeed Dan Lewis in the John Innes Institute (joining Robin Holliday and Peter Day), the Leicester Genetics Department fell into abeyance, a state from which it was rescued in 1963 by the appointment of Bob Pritchard, who built it to viable strength. Pritchard came directly from Hayes' Molecular Genetics Unit in Hammersmith and before that from Pontecorvo's department in Glasgow. Leicester now has one of our strongest Genetics Departments, particularly famous for Alec Jeffrey's invention and development of DNA 'fingerprinting'. The current Head of Department is Gabriel A. Dover, who obtained his Ph.D. with Ralph

\footnotetext{
* I am aware that I stray outside the United Kingdom at this point.
}

Riley at the Plant Breeding Institute and was until recently in the Cambridge Department of Genetics.

George Dawson, in Trinity College, Dublin*, got his Department in 1959, and stayed on to build it to its present strong position. And in 1950, the Liverpool University Department of Zoology (which already had a senior population/ecological geneticist in Arthur $\mathbf{J}$. Cain) established a Sub-department of Genetics for Philip M. Sheppard, who had come from E. B. Ford's group in Oxford. This soon became a full Department, with Sheppard in the Chair. He was a population geneticist of great distinction, and it was a great blow when he died so prematurely in 1976 . He was succeeded by Donald Ritchie from Glasgow Virology (and originally from the Bill Hayes school), with a consequent shift of emphasis in the department from population to bacterial and viral genetics.

In 1966 both Leeds and Aberdeen started new Departments of Genetics. In Leeds, I was appointed to the Chair, leaving the John Innes one year before its second move, this time from Bayfordbury to Norwich. I was followed in the Leeds Chair by David Cove in 1976. In Aberdeen the new Professor was H. John Evans, who had been a colleague of C. E. Ford at the Harwell MRC Unit. After his appointment in 1969 to the Headship of the MRC Human Cytogenetics Unit in Edinburgh, his place in Aberdeen was taken by Forbes W. Robertson, previously in the quantitative group in Waddington's department.

The University of Wales established a Department of Genetics in Swansea in 1967, with the appointment of John Beardmore (originally Thoday's student in Sheffield) to the Chair. Nottingham and Newcastleupon-Tyne followed in 1971 and 1972. The new Nottingham Professor, Bryan C. Clarke, originally a student of A. J. Cain and Philip Sheppard in Oxford, brought a strong population/ecological interest to his Department, much needed at a time when the tide was flowing so strongly in the molecular direction. Newcastle appointed Stuart W. Glover, a bacterial geneticist originally from Dawson's Dublin department and afterwards in the Hayes group, distinguished for his first genetic analysis of restriction-modification systems.

Those were the last separate University Departments of Genetics to be created. Oxford never established one, though in 1970, on E. B. Ford's retirement, it did start a new Genetics Laboratory within the Department of Biochemistry. Fisher's old student Walter Bodmer, back from a long spell at Stanford University, was the new Professor. At Oxford, Bodmer moved into human genetics, with an intensive investigation of the HLA system. Two other Universities, Hull and Manchester (1973 and 1974), established Units of Genetics associated with Botany and Zoology Depart- 
ments. Hull genetics, under David A. Jones, paralleled that at Nottingham with its population and ecological emphasis, while Manchester's specialities were mosquito genetics (R. J. Wood), cytology (R. D. Butler) and ecological genetics (L. M. Cook).

\section{Schools and mergers}

The 1960s was a time of establishment of completely new Universities. The new foundations (Keele, East Anglia, Essex, Sussex, Lancaster, York) opted from the start for integrated Departments or Schools of Biological Science, which included genetics to different extents. The genetics group in the new University of Sussex (1965) was by far the strongest: John Maynard Smith and Brian Charlesworth (population/evolutionary genetics), James H. Sang (Drosophila development), Neville Symonds and David Sherratt (bacterial and bacteriophage genetics), and Bryn Bridges heading the MRC Cell Mutagenesis Unit. Charlesworth later moved to Chicago, and Sherratt to the Chair of Genetics in Glasgow after John Pateman (following the footsteps of Hayes and Catcheside) had left for Canberra.

In more recent years, several of the once separate University Departments of Genetics have become merged in broader Departments or Schools. There appear to be two main reasons for this - a desire for economies of scale and the perception that the way forward lies in interdisciplinarity.

One consequence, perhaps paradoxical, is the splitting of the already interdisciplinary Edinburgh Genetics Department between two Institutes, centred around cells/molecules/plants and animals/populations, respectively. It did make some sense, however, to unite the animal aspects of Edinburgh Genetics with Edinburgh Zoology, which had its own strong genetical interests: in particular Aubrey Manning's behaviour genetics, Murdoch Mitchison's cell cycle group and, in the 1970 s to 1980 s, Peter Walker's MRC-funded Mammalian Genome Unit. The Mitchison laboratory launched the careers of some distinguished yeast geneticists, including Paul Nurse, and it was in Peter Walker's Unit that Ed Southern invented his indispensable blotting technique and Adrian Bird (the current holder of the Edinburgh Genetics Chair) pioneered the study of DNA methylation. Another Edinburgh zoologist, Linda Partridge, is about to take the Chair of Biometry in the Galton Laboratory at University College, London.

Undergraduate courses leading to first degrees in genetics have generally survived even where the Departments no longer exist. At the time of writing, Genetics Department at Cambridge, Leeds, Nottingham,
Glasgow and Dublin still maintain their separate status; the Department at Leicester, though part of a School of Biological Sciences for teaching purposes, also retains a clear identity.

\section{The growth of human and medical genetics}

The Galton Laboratory, which was founded as early as 1904, has remained a leading centre for research in human genetics. The Annals of Human Genetics, for many years a premier journal in its field, was always edited from the Laboratory. The post-war Galton Professors of Human Genetics have been Lionel Penrose up to 1965, Harry Harris between 1965 and 1976, and then, until recently, Elizabeth Robson. Haldane was followed in the Chair of Biometry by C. A. B. Smith. Among the Laboratory's numerous important contributions, Harris's demonstration, with D. A. Hopkinson and others, of the large amount of enzyme polymorphism in the human population, was a major landmark. Between 1962 and 1976 Harris was Director of the MRC Human Biochemical Genetics Unit, first in the University College Biochemistry Department and then in the Galton Laboratory. When Harris left for Philadelphia in 1976 the Unit was continued under D. A. Hopkinson.

Another distinguished London centre for human genetics, dating from 1946, was the MRC Blood Group Unit, first at the Lister Institute and later in association with University College. This Unit will always be associated with the names of its founding members R. R. (Rob) Race and Ruth Sanger. Race was Director until 1963, and then Sanger took over until her retirement in 1973.

During the later 1950s and 1960s there was a great increase in genetics and cytogenetics units in the hospitals. A major impetus was provided by improved techniques for human karyotype analysis and the resulting clinical applications. The big 1956 MRC initiative at the Edinburgh Western General Hospital has already been mentioned. Before long, most of the larger hospitals had cytogenetics laboratories.

In several Universities, links were established between clinical and academic departments. In Glasgow, the pioneer in clinical cytogenetics was M. A. (Malcolm) Ferguson-Smith; he was, in the 1960s, a member of the University Genetics Department and, in 1974, became the Head of a new Department of Clinical Genetics, a position that he held until his move to Cambridge (University Pathology Department and Addenbrooke's Hospital) in 1989. In Birmingham the leader was John H. Edwards, a population geneticist and paediatrician. He moved in 1961 from an M.R.C. Unit of Population Genetics in Oxford to the Bir- 
mingham University Department of Social Medicine; in 1969 he became Professor of Human Genetics in the University and Head of the Department of Clinical Genetics at the Birmingham Maternity Hospital. He moved back to Oxford to succeed Walter Bodmer as Head of the Genetics Laboratory in 1979. Oxford already had strength in human/clinical genetics in the person of David (now Sir David) Weatherall, a world leader in the characterization of genetic haemoglobin deficiencies and Professor of Clinical Medicine.

Over the last decade the leading hospital-associated laboratories have become more molecular in orientation, adding the probing and analysis of DNA sequences to their previous cytological expertise. At St. Mary's Hospital, London, for example, R. (Bob) Williamson's group has been among the vanguard of human gene cloners.

An increasing role in human cytogenetic analysis has been taken by the Cancer Research Institutes, of which the Imperial Cancer Research Fund (ICRF) Laboratory in London, headed since 1979 by Walter Bodmer, must be the strongest. The ICRF has many advances in human cellular and molecular genetics to its credit, an outstanding example being the discovery by Peter Goodfellow (in collaboration with Robin LovellBadge's group at NIMR) of the male-determining element on the Y-chromosome. The ICRF has also undertaken research in basic molecular and cell genetics, especially in relation to the control of cell division, a field to which Paul Nurse (the Genetical Society's present President) has contributed notably.

Peter Goodfellow has recently (1992) taken the Chair of Genetics in Cambridge. With the two adjacent Departments, Genetics and Pathology, headed respectively by Goodfellow and Ferguson-Smith, Cambridge University is now exceptionally strong in human genetics. With the human organism now virtually on a par with Drosophila as an object of intensive genetic study, we can expect a greater emphasis on human genetics in University biology, both inside and outside the Medical Schools.

\section{The Plant and Animal Institutes}

Over the post-war period, several plant and animal research establishments outside Universities have been supported by the Agricultural Research Council (ARC - now the AFRC with the addition of Food to its remit), and some of these have been in the forefront of genetical research.

\section{The John Innes Institute}

In its later Bayfordbury days, the JII included a strong Cell Biology Department under Henry (not Harry)
Harris, not much concerned with plants. The Genetics Department took on a rather fungal emphasis, with my work on allelic complementation in Neurospora, Peter Day's analysis (following Dan Lewis) of mating type in Coprinus and, most notably, Robin Holliday's Ustilago work which led to his path-breaking general model of recombination. I claim some credit, with Brian Harrison, for resurrecting the work on genetic instability (now known to be due to transposable elements) in the snapdragon, Antirrhinum majus. This fascinating system had been set aside since Kenneth Mather made it the subject of his Ph.D. thesis in 1933. There was also a department of Potato Genetics, where Norman Simmonds was engaged upon an enterprising project designed to broaden the genetic base of the cultivated potato by going back to the Andes. Jeffrey Harborne carried on his masterly analyses of plant pigments, in direct succession to Rose Scott-Moncrieff, whose prewar work at Merton, prompted by Haldane, was one of the green shoots of biochemical genetics.

The move of the Institute from its idyllic Bayfordbury site to Norwich in 1967 was the consequence of a Government Report that decreed that small Institutes doing fundamental research should be located in close proximity to Universities. The new University of East Anglia seized its chance. By the time of the move in 1967, the Director, Kenneth Dodds, had retired, Harris had moved to a Chair in Oxford, Simmonds to direct the Scottish Plant Breeding Station, and I to Leeds to start the new University Genetics Department there. Peter Day and Robin Holliday had departed some years previously, for Connecticut and the NIMR, respectively (Day returned in the 1980s to become Director of the Plant Breeding Institute - the last Director as it turned out). The JII was at a low ebb, but under its new Director, Roy Markham the plant virologist, it rose on its new site like a phoenix from the ashes. Under the more recent Directorships of Harold Woolhouse and Richard B. Flavell it has continued to gather strength. In the Genetics Department, David Hopwood and Keith Chater's group lead the world in Streptomyces genetics, and Enrico Coen and his colleagues have used various transposable elements in Antirrhinum as gene tags to help open up a new field of plant developmental genetics.

\section{The Plant Breeding Institute/Cambridge Laboratory}

The PBI at Cambridge worked on a number of different crop plants, but its most famous achievements were with wheat and barley. In wheat, Ralph Riley and Colin Law developed E. R. Sears' aneuploid analysis to a high art. This elegant wheat cytogenetics provided the background for an extraordinarily successful breeding programme, due largely to John Bingham. 
PBI-bred varieties of both wheat and barley made major impacts on the market. The Institute always combined practical breeding with basic plant science. From the mid-1970s, Richard Flavell and his colleagues at the PBI were among the first to apply the new DNA technology to plants, with an initial concentration on repetitive sequences and the nucleolus organizer.

In the political climate of the $1980 \mathrm{~s}$, and given the difficulty that the AFRC was having in funding all of its Institutes, the PBI's commercial success made it a prime target for privatization. This is not the place to detail the somewhat confused circumstances surrounding the lucrative sale in 1987 of the breeding side of the PBI (not the basic science) to Unilever. Suffice it to say that, because of the status of the PBI as a Charity, the lucre finished up, not in the hands of the AFRC or the Treasury as everyone had expected, but rather with the Governors of the Institute. Now the Governors, deprived for the time being of AFRC support but careful to retain AFRC goodwill, maintain the Cambridge Laboratory (as the non-privatized part of the PBI is now called) in a well-equipped new building on the John Innes site in Norwich.

The move of the Cambridge Laboratory to the John Innes site followed shortly after the construction there of the Sainsbury Laboratory, funded by the grocer and philanthropist David Sainsbury. This laboratory specializes in molecular plant pathology, and has a strong genetical aspect. With all three Institutions, JII, Cambridge and Sainsbury, working in liaison on the same site, and with significant strength in molecular plant genetics in the nearby University of East Anglia, Norwich may well be the strongest centre for genetically oriented plant science in the world.

\section{Animal Institutes}

On the animal side, the institute most focused on genetics was $\mathrm{ABRO}$ in Edinburgh, though the nearby Poultry Research Centre (PRC, founded in 1947) also did some genetical research. ABRO had close links with the ARC Unit of Animal Genetics in the University until the Unit was discontinued on Douglas Falconer's retirement in 1980. Some of ABRO's most successful work was in pig breeding (John King) and selection theory (Charles Smith). In more recent years A. John Clark has been making transgenic sheep, more with a view to pharmaceuticals than to improved meat or wool production.

The ARC/AFRC Institute for Animal Physiology at Babraham, near Cambridge, dates from before the war. It acquired some genetical fame during the last decade or so, with the work of Azim Surani and his colleagues on sex-specific genomic imprinting in mouse. In 1986, ABRO, the PRC and Babraham (the first two amalgamated on the PRC site at Roslin) were all placed under a single AFRC umbrella - the AFRC Institute for Animal Physiology and Genetics Research. The separation of 350 miles made joint administration difficult, and the physiology and genetics are now once again separated under new names - the AFRC Babraham Institute and the AFRC Roslin Institute (Edinburgh), the latter headed by Grahame Bulfield.

The former ABRO building on the Edinburgh University science campus is now occupied by a University/AFRC Interdisciplinary Research Centre for Genome Research (CGR), under the leadership of Richard Lathe and John Bishop. The CGR has a special interest in the potential of transgenic animals. With the Roslin Institute, the CGR and the University Institute of Cell Animal and Population Biology (which includes the breeding and population interests of the former Institute of Animal Genetics), Edinburgh has a position of dominance in U.K. animal genetics comparable to that of Norwich in plant genetics.

\section{The rise of molecular developmental genetics}

The long-standing ambition of geneticists to be able to trace the connections between the genotype and the phenotype has, over the last decade or so, begun to be realized as never before. The key, of course, has been molecular biology. The molecular analysis of development is being pursued in a number of University departments of Zoology and Genetics, as well as in research establishments. In the forefront, just as it was in basic molecular genetics, is the Cambridge MRC Laboratory of Molecular Biology. One need only mention Peter Lawrence's work on compartments in Drosophila or Jonathan Hodgkin's on sex determination in Caenorhabditis. Some of the most original mouse work has been at Babraham (Azim Surani, imprinting), and the NIMR (Robb Krumlauf, Hox gene clusters). The MRC Human Genetics Unit in Edinburgh has also been increasingly involved in molecular studies of mouse development.

In Cambridge, the Cancer Research Campaign and the Wellcome Trust have come together to establish a new Institute of Cancer and Developmental Biology. It brings together, among others, John Gurdon and Ron Laskey from Cambridge Zoology, Martin Evans and Michael Akam from Cambridge Genetics, Azim Surani from Babraham, and Anne McLaren from the MRC Mammalian Development Unit in London. The range of animals to be studied includes frogs, mice, insects and no doubt others. This development illustrates two features of the current scene: the 
tendency for the strongest research groups to become concentrated in a few leading establishments, and the abandonment of previous departmental boundaries.

Can all this be claimed as part of our subject of Genetics? The answer is arguably yes, but, if so, we are laying claim to practically the whole of modern developmental biology.

\section{Is there a genetics community?}

Whereas, in 1945, genetics was a minority interest among biologists, viewed by most as specialized, unintelligible or just irrelevant, it has now penetrated into every corner of biological science. Most biologists would now recognize it as being at the root of everything. This is a source of great satisfaction, but it also creates something of an identity crisis for geneticists. What is Genetics? How do we distinguish ourselves from molecular biologists or biochemists, when half the papers in any leading molecular biological or biochemical journal are about identification of gene products and control of gene expression?

The other side of the geneticists' identity problem is the difficulty that people who are actually card-carrying geneticists have in maintaining common interests and a common pool of knowledge. Immediately after the war the British Genetical Society numbered only a hundred or so, and Society meetings consisted of common sessions of unsolicited contributions. Diverse as their interests were, the members managed to be interested in most of what they heard. As the membership grew (its present strength is in excess of 1500) community of interest became more difficult to maintain. Bacterial genetics was a new world with a special jargon and set of concepts that some of those outside the club found very difficult. Fungal genetics evoked enthusiasm in some and boredom in others. Molecular genetics had little apparent relevance to the population/ecological wing, and vice versa. Those whose expositions involved mathematics talked effectively only to each other. And even with the best will in the world, it was becoming impossible to keep up with the expansion of knowledge in every area.

From the $1960 \mathrm{~s}$, the Genetical Society started to include in each meeting both multiple concurrent sessions of contributed papers and symposia, the idea of the latter being to review special fields for non-specialized audiences. However, although the symposia were usually excellent in their own terms, they were often, as it turned out, directed mainly to the specialists. From the $1960 \mathrm{~s}$, the population geneticists began to organize their own 'Pop Group' meetings, which became rather better attended than the Society meetings intended for the membership at large. Over the last few years, the Society has tended to abandon general sessions of contributed papers in favour of special symposia for special interests.

Another frank acknowledgement of diversity is the publication of two Society journals: Heredity, a gift to the Society from C. D. Darlington in 1971, and Genes and Development, founded on the profits from Heredity and started in conjunction with Cold Spring Harbor in 1987. My guess is that hardly anybody contributing to the one journal would think of sending a paper to the other.

So do we any longer have an identifiable subject? Perhaps we should stop worrying and adopt a pragmatic definition of a geneticist, perhaps as a person who thinks it worthwhile to subscribe to a Genetical Society. An alternative definition is someone prepared to attend and even to help organize an International Congress of Genetics. 